\title{
GAMBARAN PROGRAM GENERASI BERENCANA (GENRE) DI INDONESIA DAN DI PROVINSI JAWA TIMUR TAHUN 2017
}

\author{
Ita Mustofa Rini ${ }^{1}$, Yuni Dwi Tjadikijanto ${ }^{2}$ \\ ${ }^{1}$ Departemen Biostatistika \& Kependudukan \\ Fakultas Kesehatan Masyarakat Universitas Airlangga \\ Jalan Mulyorejo Kampus C Unair Surabaya 60115 \\ ${ }^{2}$ Perwakilan BKKBN Provinsi Jawa Timur \\ Jl. Airlangga No. 31-33, Airlangga, Gubeng \\ Kota Surabaya, Jawa Timur 60286 \\ Alamat Korespondensi: Ita Mustofa Rini \\ Email: ita.mustofa.rini-2016@fkm.unair.ac.id
}

\begin{abstract}
The success of a nation in the future will be largely determined by the quality of adolescents in the present. Therefore, adolescent's personal life must be prepared as early as possible in order to achieve optimal quality. The main program that support the achievement of youth quality is the Generasi Berencana (GenRe) program. This research aims to analyze the description of GenRe program implementation in Indonesia and in East Java Province based on the 2017 Survey of performance indicators on Population Program, Family Planning and Family Development. This study focuses on increasing age of first marriage, adolescent resproductive health, family development program for adolescent and Counseling Information Centers for Youth. Study found that GenRe program which covers three indicators in both Indonesia and East Java is still unoptimally implemented. In order to maximize the implementation of GenRe, this study suggest to increase the knowledge and exposure of information regarding three indicators of the GenRe Program for adolescents, families who have teenage family members and communities in the territory of Indonesia, especially in East Java Province.
\end{abstract}

Keywords: adolescent, reproductive, health, generasi berencana

\begin{abstract}
ABSTRAK
Keberhasilan dan kesuksesan sebuah bangsa di masa yang akan datang sangat ditentukan oleh kualitas remaja pada masa sekarang. Kehidupan diri remaja harus disiapkan sedini mungkin agar tercapai kualitas yang optimal. Program utama yang mendukung tercapainya kualitas remaja adalah program Generasi Berencana (GenRe). Penelitian ini bertujuan untuk menggambaran pelaksanaan program GenRe di Indonesia dan di Provinsi Jawa Timur berdasarkan hasil survey indikator kinerja Program Kependudukan, Keluarga Berencana Dan Pembangunan Keluarga (KKBPK) dalam Rencana Pembangunan Jangka Menengah Nasional (RPJMN) tahun 2017 yang meliputi Pendewasaan Usia Perkawinan (PUP), Kesehatan Reproduksi Remaja (KRR) dan Bina Keluarga Remaja (BKR) \& Pusat Informasi Konseling pada Remaja/Mahasiswa (PIK R/M). Hasil penelitian menunjukkan bahwa program GenRe yang meliputi ketiga indikator tersebut baik di Indonesia maupun di Jawa Timur belum terlaksana secara optimal. Angka pernikahan remaja usia 10-19 tahun masih tinggi, di Indonesia sebesar $44,70 \%$, di Jawa Timur sebesar 47,50\%. Keterpaparan informasi mengenai KRR masih rendah, di Indonesia sebesar 25,20\%, dan di Jawa Timur sebesar 24,70\%, Keterpaparan informasi mengenai BKR juga masih rendah, di Indonesia sebesar 26\%, dan di Jawa Timur sebesar 25,60\%. Demikian pula dengan keterpaparan informasi mengenai PIK Remaja/Mahasiswa masih rendah di Indonesia sebesar 11,90\%, dan di Jawa Timur sebesar $11 \%$. Guna mengoptimalkan Program GenRe maka perlu dilaksanakan upaya peningkatan pengetahuan \&keterpaparan informasi mengenai PUP, KRR, BKR \& PIK R/M pada remaja dan keluarganya serta masyarakat secara luas.
\end{abstract}

Kata kunci: kesehatan, reproduksi, remaja, generasi berencana

Received: 26 September 2018

Published: 31 Desember 2018

\section{PENDAHULUAN}

Keberhasilan dan kesuksesan sebuah bangsa di masa yang akan datang akan sangat ditentukan oleh kualitas remaja pada masa sekarang. Oleh karena itu seharusnya masa remaja perlu mendapatkan perhatian dan pengawasan khusus, agar para remaja dapat melaluinya sesuai dengan tahap perkembangan dan pertumbuhannya sehingga tercipta remaja yang memiliki kualitas yang optimal. 
Masa remaja merupakan masa peralihan dari masa kanak-kanak ke masa dewasa. Menurut WHO batasan usia remaja adalah 10 tahun hingga 19 tahun. Batasan usia remaja yang digunakan oleh BKKBN adalah 10-24 tahun dan belum menikah. Sedangkan menurut Peraturan Menteri Kesehatan No 25 tahun 2014, batasan usia remaja adalah 10 tahun hingga 18 tahun.

Jumlah Penduduk usia remaja (10-24 tahun) sangat besar yakni mencapai $27,6 \%$ dari seluruh penduduk yang ada di Indonesia (BPS, 2013). Dengan mempertimbangkan jumlah remaja yang sangat besar, maka perlu dilaksanakan upaya dalam rangka mempersiapkan remaja menjadi manusia yang sehat secara jasmani, rohani, mental sosial dan spiritual. (BKKBN, 2014). Hal yang perlu di waspadai pula terkait dengan meningkatnya jumlah remaja adalah muculnya berbagai permasalahan yang terkait dengan remaja. Permasalahan yang paling banyak terjadi pada remaja adalah masih tingginya persentase pernikahan usia dini yakni sebesar 44,70\%, persentase pengetahuan remaja tentang Generasi Berencana/Kesehatan Reproduksi Remaja (KRR) yang masih rendah yakni sebesar $48,4 \%$ pada survei Rencana Jangka Panjang Menengah Nasional (RPJMN) 2014 dan sedikit meningkat pada tahun 2015 menjadi 49\%, dan tahun 2016 turun drastis menjadi 32,2\% (BKKBN, 2017a). Sesuai dengan Renstra BKKBN 2015-2019 menyebutkan bahwa indeks pengetahuan remaja tentang KRR pada tahun 2018 harus mencapai $51 \%$ dari total remaja yang ada serta masih rendahnya keterpaparan informasi mengenai Bina Keluarga Remaja (BKR) yakni sebesar 26\% dan Pusat Informasi \& Konseling bagi Remaja/Mahasiswa (PIK R/M) yang hanya mencapai $11 \%$. Guna merespon, mengantisipasi dan meminimalisir permasalahan yang terjadi di kalangan remaja tersebut maka BKKBN mengembangkan Program Generasi Berencana (GenRe).

Program GenRe merupakan suatu program yang dikembangkan dan dilaksanakan untuk mempersiapkan kehidupan berkeluarga bagi remaja/mahasiswa agar tercapai tegar remaja/mahasiswa sehingga ke depan dapat mewujudkan tegar keluarga demi terwujudnya keluarga kecil, bahagia dan sejahtera (BKKBN, 2014). Pelaksanaan program GenRe meliputi dua hal diantaranya adalah melalui pendekatan kepada remajanya langsung yang melalui kegiatan PIK/RM dan pendekatan kepada keluarga yang mempunyai anak berusia remaja melalui wadah BKR (BKKBN, 2017a).

Optimalisasi program Generasi Berencana (GenRe) perlu dilakukan salah satunya adalah dengan membandingkan antara gambaran pelaksanaan program GenRe pada lingkup skala nasional (di wilayah Indonesia secara keseluruhan) dan di Provinsi Jawa Timur berdasarkan hasil survei indikator RPJMN Keluarga tahun 2017.

\section{METODE PENELITIAN}

Metode penelitian yang digunakan dalam penelitian ini adalah metode deskriptif yaitu metode penelitian yang menggambarkan hasil analisis Program GenRe di wilayah Indonesia secara keseluruhan dan di Provinsi Jawa Timur pada tahun 2017.

Responden remaja pada penelitian survei tersebut adalah remaja laki-laki dan remaja perempuan yang berusia 15-24 tahun, dengan status belum menikah dan keluarga yang mempunyai anggota keluarga berusia remaja.

Sampel penelitian diperoleh dari sampel keluarga. Pengertian keluarga merupakan bagian terkecil dari masyarakat yang terdiri dari pasangan usia subur (suami istri), suami isteri dan anaknya, ayah dengan anaknya atau ibu dengan anaknya (UU RI No. 52, 2009). Batasan yang dimaksud dengan anak adalah anak yang belum menikah. Apabila ada anak yang sudah menikah dan tinggal bersama dengan pasangannya, walaupun masih serumah dengan orang tuanya, maka yang anak tersebut sudah dianggap menjadi keluarga sendiri.

Besar sampel pada survey tersebut sebanyak 27.187 orang dan yang berhasil di wawancarai secara lengkap sebanyak $87.6 \%$, yaitu remaja yang belum menikah dan berusia 15-24 tahun, tinggal atau bermukim bersama keluarga dalam satu rumah sekurang kurangnya selama 6 (enam) bulan.

Variabel yang dianalisis dalam penelitian ini meliputi tiga variabel yang mendukung pelaksanaan program GenRe yaitu Pendewasaan Usia Perkawinan (PUP), Pengetahuan dan keterpaparan informasi KRR, BKR dan PIK R/M tahun 2017.

Penelitian ini menggunakan data sekunder yang di peroleh dari hasil survey RPJMN tahun 2017. 


\section{HASIL PENELITIAN}

Hasil penelitian ini diuraikan berdasarkan tiga komponen yang merupakan bagian dari pelaksanaan program GenRe yang meliputi Pendewasaan Usia Perkawinan (PUP), Pengetahuan dan keterpaparan informasi mengenai Kesehatan Reproduksi Remaja (KRR) serta keterpaparan informasi mengenai Bina Keluarga Remaja (BKR) dan Pusat Informasi \& Konseling bagi Remaja/Mahasiswa (PIK R/M).

\section{Pendewasaan Usia Perkawinan (PUP)}

PUP merupakan sebuah upaya yang telah dilaksanakan oleh BKKBN dalam rangka untuk mendewasakan usia perkawinan pertama kali. Seseorang diperbolehkan menikah untuk pertama kalinya jika telah mencapai usia sekurang-kurangnya 21 tahun bagi seorang perempuan dan sekurang-kurangnya berusia 25 tahun bagi seorang laki-laki. (BKKBN, 2014).

Tujuan dari program PUP ini diantaranya adalah untuk menciptakan pasangan suami istri yang telah siap dalam membina dan mempersiapkan rumah tangga baik mencapai kematangan secara fisik maupun secara psikis, mental dan sosial, sehingga dengan tercapainya usia yang matang dan telah siap untuk menikah diharapkan dapat mewujudkan sebuah keluarga yang berkualitas baik.

Hasil survei indikator RPJMN Tahun 2017 khususnya pada program PUP didapatkan gambaran data seperti yang tertera dalam tabel 1. Gambaran usia pertama kali menikah yang di dapatkan dari tabel 1 menggambarkan bahwa pernikahan yang terjadi pada usia kurang dari 20 tahun di Indonesia masih tinggi yakni sebesar $44,70 \%$ bahkan masih ada pernikahan yang terjadi di usia yang sangat ekstrim yaitu pada usia 10-14 tahun yakni sebesar $5,10 \%$.
Demikian halnya dengan yang terjadi di Jawa Timur. Pernikahan yang terjadi pada usia kurang dari 20 tahun juga masih tinggi bahkan lebih tinggi jika dibandingkan dengan di wilayah seluruh Indonesia secara keseluruhan yakni mencapai sebesar $47,50 \%$ dari total pernikahan yang terjadi pada wanita usia subur. Pernikahan pada usia ekstrim juga masih terjadi yakni pada usia 10-14 tahun yang jumlahnya mencapai $5,30 \%$ dan persentasenya lebih tinggi dari wilayah Indonesia secara keseluruhan.

Rata-rata umur pertama kali menikah pada WUS di Indonesia masih tergolong pada usia muda yakni berusia 20 tahun, sedangkan di Jawa Timur justru lebih rendah yakni terjadi pada usia 19 tahun.

Indikator program PUP juga tidak terlepas dari peran serta keluarga. Berdasarkan data dari hasil survei RPJMN Tahun 2017 dapat digambarkan bahwa di Indonesia masih ada keluarga yang mempunyai pendapat setuju terhadap remaja yang menikah pada usia sebelum 20 tahun yakni sebesar $14,50 \%$ dan bahkan sangat setuju yakni sebesar $0,6 \%$.

Di Jawa Timur juga menggambarkan hal yang sama di mana masih terdapat juga keluarga yang setuju yakni sebesar 13,90\% dan sangat setuju $0,70 \%$ jika ada anggota keluarganya yang berusia remaja menikah di bawah usia 20 tahun. Meskipun jumlahnya tidak terlalu besar dan masih berada di bawah wilayah Indonesia secara keseluruhan tetapi hal ini perlu mendapatkan perhatian.

Hasil survei RPJMN Tahun 2017 mengenai distribusi persentase pendapat keluarga tentang remaja yang menikah sebelum usia 20 tahun yang dikelompokkan dalam sangat setuju, tidak setuju, netral, setuju dan sangat setuju mengenai remaja yang menikah sebelum 20 tahun dapat digambarkan pada tabel 2 .

Tabel 1. Distribusi Persentase Pernikahan pada Wanita Usia Subur (WUS) Menurut Umur Pertama Kali Menikah

\begin{tabular}{lccccccc}
\hline \multirow{3}{*}{ Wilayah } & \multicolumn{4}{c}{ Umur Pertama Kali Menikah } & \multirow{2}{*}{$\begin{array}{c}\text { Rata-rata Umur } \\
\text { Pertama Kali Menikah }\end{array}$} \\
\cline { 2 - 7 } & $\mathbf{1 0 - 1 4}$ tahun & $\mathbf{1 5}-\mathbf{1 9}$ tahun & $\mathbf{2 0 - 2 4}$ tahun & (th) \\
\cline { 2 - 7 } & $\mathbf{n}$ & $\mathbf{\%}$ & $\mathbf{n}$ & $\mathbf{\%}$ & $\mathbf{n}$ & $\mathbf{\%}$ & 20 \\
\hline Indonesia & 2.699 & 5,10 & 20.724 & 39,60 & 18.212 & 34,80 & 19 \\
Jawa Timur & 99 & 5,30 & 785 & 42,20 & 642 & 34,50 & \\
\hline
\end{tabular}


Tabel 2. Distribusi Persentase Keluarga Menurut Pendapat Tentang Remaja Menikah Sebelum Usia 20 Tahun

\begin{tabular}{cccccccccccc}
\hline & \multicolumn{3}{c}{ Pendapat Keluarga Mengenai Remaja yang Menikah Sebelum 20 Tahun } \\
\cline { 2 - 12 } Wilayah & $\begin{array}{c}\text { Sangat } \\
\text { Tidak Setuju }\end{array}$ & \multicolumn{2}{c}{ Tidak Setuju } & \multicolumn{2}{c}{ Netral } & \multicolumn{2}{c}{ Setuju } & \multicolumn{2}{c}{$\begin{array}{c}\text { Sangat } \\
\text { Setuju }\end{array}$} \\
\cline { 2 - 13 } & $\mathbf{n}$ & $\mathbf{\%}$ & $\mathbf{n}$ & $\mathbf{\%}$ & $\mathbf{n}$ & $\mathbf{\%}$ & $\mathbf{n}$ & $\mathbf{\%}$ & $\mathbf{n}$ & $\mathbf{\%}$ \\
\hline Indonesia & 3.697 & 5,50 & 39.192 & 58,30 & 14.184 & 21,10 & 9.748 & 14,50 & 403 & 0,60 \\
Jawa Timur & 160 & 4,50 & 2.123 & 59,80 & 753 & 21,20 & 493 & 13,90 & 24 & 0,70 \\
\hline
\end{tabular}

Tabel 3. Distribusi Persentase Keluarga yang Pernah Mendengar/Melihat/Membaca Informasi Berkaitan dengan KRR

\begin{tabular}{|c|c|c|c|c|}
\hline \multirow{3}{*}{ Wilayah } & \multicolumn{4}{|c|}{$\begin{array}{c}\text { Persentase Keluarga Pernah Mendengar/Melihat/Membaca Informasi } \\
\text { Berkaitan dengan KRR }\end{array}$} \\
\hline & \multicolumn{2}{|c|}{ Pernah mendengar } & \multicolumn{2}{|c|}{ Tidak Pernah Mendengar } \\
\hline & $\mathbf{n}$ & $\%$ & $\mathbf{n}$ & $\%$ \\
\hline Indonesia & 50.284 & 74,80 & 16.940 & 25,20 \\
\hline Jawa Timur & 2.675 & 75,30 & 878 & 24,70 \\
\hline
\end{tabular}

Tabel 4. Trend Indeks Pengetahuan Remaja dan Orang Tua/Keluarga yang Mempunyai Anggota Keluarga Berusia Remaja Mengenai KRR

\begin{tabular}{ccccccc}
\hline \multirow{2}{*}{ Wilayah } & \multicolumn{7}{c}{ Persentase Indeks Pengetahuan KRR Per Tahun } \\
\cline { 2 - 7 } & $\mathbf{2 0 1 2}$ & $\mathbf{2 0 1 3}$ & $\mathbf{2 0 1 4}$ & $\mathbf{2 0 1 5}$ & $\mathbf{2 0 1 6}$ & $\mathbf{2 0 1 7}$ \\
\hline Indonesia & 50,5 & 49,6 & 41,9 & 47,6 & 22,6 & 37,6 \\
Jawa Timur & 53,4 & 52,9 & 46 & 45,2 & 14,2 & 37,6 \\
\hline
\end{tabular}

\section{Kesehatan Reproduksi Remaja}

Kesehatan Reproduki Remaja (KRR) merupakan suatu kondisi yang sehat dari seorang diri remaja yang meliputi kesehatan dalam sistem, fungsi dan proses reproduksi, tidak semata-mata hanya terbebas dari suatu gangguan kesehatan maupun ketidak normalan saja tetapi juga terwujudnya kesehatan secara keseluruhan yang meliputi sehat secara mental dan sosial kultural. Informasi mengenai KRR merupakan hal yang sangat penting bagi diri seorang remaja untuk memahami mengenai kesehatan reproduksinya sekaligus mengetahui berbagai permasalahannya.

Informasi mengenai KRR dapat diperoleh dari berbagai macam sumber baik dari media massa, media elektronik maupun media cetak yang dapat disampaikan oleh tenaga kesehatan, guru, tokoh masyarakat dan tokoh agama di sekitar lingkungan para remaja dan keluarganya. Selain informasi yang berkaitan dengan KRR, hal yang perlu dianalisis lanjut adalah trend mengenai Indeks pengetahuan remaja $\&$ orang tua/keluarga yang mempunyai anggota keluarga berusia remaja mengenai KRR. Trend ini dapat menunjukkan sejauh mana keberhasilan program tersebut dilaksanakan.

Data dari sumber yang sama menggambarkan bahwa indeks pengetahuan KRR baik pada remajanya sendiri maupun pada keluarga yang memiliki anggota keluarga berusia remaja di Indonesia dan di Jawa Timur menggambarkan capaian angka yang masih sangat rendah yakni baru mencapai 37,6\%.

Trend mengenai Indeks pengetahuan remaja dan orang tua/keluarga yang mempunyai anggota keluarga berusia remaja mengenai KRR dalam survey RPJMN tahun 2017 digambarkan selama 5 tahun yakni mulai tahun 2012-2017 masih menunjukkan gambaran yang fluktuatif sebagaimana dapat dilihat pada tabel 4 .

\section{Bina Keluarga Remaja (BKR) dan Pusat Informasi Konseling pada Remaja /Mahasiswa (PIK R/M)}

Di Indonesia dan di Jawa Timur persentase keluarga yang pernah mendengar/ melihat/ membaca informasi yang berkaitan dengan BKR masih rendah yakni di Indonesia hanya sebesar $26 \%$ dan di Jawa Timur sebesar $25,60 \%$. 
Tabel 5. Distribusi Persentase Keluarga yang Mendengar/Melihat/Membaca Informasi Berkaitan dengan BKR dan PIK R/M

\begin{tabular}{|c|c|c|c|c|c|c|}
\hline \multirow{3}{*}{ Wilayah } & \multicolumn{6}{|c|}{$\begin{array}{l}\text { Persentase Keluarga yang Mendengar/Melihat/Membaca } \\
\text { Informasi Berkaitan dengan BKR dan PIK R/M }\end{array}$} \\
\hline & \multicolumn{2}{|c|}{ BKR } & \multicolumn{2}{|c|}{ PIK R/M } & \multicolumn{2}{|c|}{ Tidak Tahu } \\
\hline & $\mathbf{n}$ & $\%$ & n & $\%$ & $\mathbf{n}$ & $\%$ \\
\hline Indonesia & 17.478 & 26,00 & 8.000 & 11,90 & 31.595 & 47,00 \\
\hline Jawa Timur & 910 & 25,60 & 391 & 11,00 & 1.546 & 43,50 \\
\hline
\end{tabular}

Demikian pula dengan persentase keluarga yang pernah mendengar /melihat/membaca informasi berkaitan PIK R/M juga sangat rendah yakni di wilayah Indonesia hanya sebesar $11,90 \%$ dan di Jawa Timur hanya sebesar $11 \%$. Gambaran Distribusi persentase mengenai kedua hal tersebut berdasarkan Survei RPJMN Tahun 2017 dapat digambarkan seperti pada tabel 5 .

Berdasarkan sumber yang sama, dari sisi remajanya sendiri disebutkan bahwa persentase remaja yang pernah mendengar PIK R/M baru mencapai $22 \%$ dan yang telah mengikuti PIK $\mathrm{R} / \mathrm{M}$ sebesar $20 \%$. Informasi mengenai PIK $\mathrm{R} / \mathrm{M}$ ini didapatkan remaja dari pendidik sebaya, konselor sebaya dan dari berbagai sumber lain baik media cetak maupun media elektronik.

\section{PEMBAHASAN}

\section{Pendewasaan Usia Perkawinan (PUP)}

Terjadinya pernikahan pada usia dini yang masih sangat tinggi baik di wilayah Indonesia secara keseluruhan maupun di Jawa Timur. Hal ini menunjukkan bahwa program Generasi Berencana yang terkait dengan Pendewasaan Usia Perkawinan (PUP) belum berhasil dilaksanakan secara maksimal.

PUP merupakan sebuah upaya yang telah dilaksanakan oleh BKKBN dalam rangka untuk mendewasakan usia perkawinan pertama kali. Seseorang diperbolehkan menikah untuk pertama kalinya jika telah mencapai usia sekurang-kurangnya 21 tahun bagi seorang perempuan dan sekurang-kurangnya berusia 25 tahun bagi seorang laki-laki (BKKBN Provinsi Jawa Timur, 2014).

Dalam rangka mewujudkan kesiapan fisik, mental, emosional, pendidikan, sosial, ekonomi dan menentukan jumlah dan jarak kelahiran anak, maka program PUP mutlak untuk dilaksanakan. Jika ternyata gagal dalam mendewasakan usia perkawinan maka setidaknya remaja perlu menunda dulu kelahiran anak pertamanya sampai memasuki usia yang ideal.

Hasil survei indikator RPJMN tahun 2017 yang menggambarkan bahwa umur rata-rata menikah pada remaja di Jawa Timur adalah 19 tahun. Umur tersebut lebih muda jika dibandingkan rata rata umur remaja menikah di Indonesia yang sudah mencapai 20 tahun.

Penelitian yang telah dilakukan oleh Mahfudin \& Khoirotul (2016) mengenai faktor penyebab pernikahan dini di Kbupaten Sumenep Jawa Timur menyatakan bahwa penyebab pernikahan dini diantaranya adalah faktor ekonomi dimana pernikahan dini dilakukan dengan alasan untuk mengurangi beban ekonomi keluarga keluarga, faktor kemauan sendiri dari diri remaja yang merasa sudah saling mencintai, Faktor pendidikan yaitu kurangnya pengetahuan orang tua dan anak, faktor keluarga dan faktor adat di mana ada kebiasaan orang tua mencarikan jodoh untuk anaknya.

Penelitian lain menyebutkan pula bahwa salah satu faktor yang mempengaruhi tingginya kejadian pernikahan di usia muda ketidak tahuan remaja terhadap perkawinan usia muda itu sendiri. Remaja tidak memahami mengenai apa yang dimaksud dengan pendewasaan usia perkawinan, berapa usia ideal bagi seseorang untuk diperbolehkan menikah (Banderan, et.al., 2017).

Hal ini sesuai dengan hasil survei indikator RPJMN tahun 2017 yang menggambarkan bahwa masih ada keluarga yang setuju bahkan sangat setuju mengenai pendapat tentang remaja menikah sebelum usia 20 tahun yakni mencapai 14,6\% (Jawa Timur) dan 15\% (Indonesia).

Usia kawin pertama merupakan indikator sosial demografi yang sangat penting. Sesuai dengan analisis hasil survey indikator RPJMN 2017 menyebutkan bahwa hubungan seksual pertama kali biasanya dilakukan bertepatan dengan perkawinan pertama. Hubungan 
seksual merupakan awal seseorang berisiko hamil. Dengan demikian maka jika suatu masyarakat melakukan perkawinan pada usia yang sangat muda maka angka kelahiran yang terjadi juga cenderung lebih tinggi (BKKBN, 2017a).

Faktor lain yang juga menyebabkan masih tingginya pernikahan usia muda juga disebabkan karena pengetahuan keluarga mengenai BKR juga masih rendah yakni di Indonesia hanya mencapai $26 \%$, sedangkan di Jawa Timur justru lebih rendah yakni hanya mencapai $25,60 \%$. Demikian pula dengan pengetahuan keluarga mengenai Program Informasi dan Konseling pada Remaja/Mahasiswa sangat rendah. Di Indonesia hanya mencapai $11,90 \%$ dan di Jawa Timur hanya $11,00 \%$ (BKKBN, 2017a).

Tingginya kasus pernikahan dini yang terjadi baik di Indonesia maupun di Jawa Timur seharusnya mendapatkan perhatian yang utama untuk penanganannya. Hal ini berkaitan erat dengan laju pertumbuhan penduduk dan masa depan generasi muda bangsa (Desiyanti, 2015). Dengan demikian jika kondisi pernikahan usia dini yang terjadi di Indonesia dan Jawa Timur tidak dapat diturunkan secara signifikan maka hal ini berarti bahwa program Generasi Berencana di Indonesia dan Jawa Timur tidak dapat berjalan secara optimal, sehingga dimungkinkan akan membawa dampak meningkatnya angka fertilitas yang akan memberikan dampak buruk bagi kesejahteraan masyarakat.

Penelitian ini juga menunjukkan bahwa orang tua memiliki peran terhadap terjadinya pernikahan remaja pada usia kurang dari 20 tahun. Bila responden keluarga yang memberikan pendapat setuju atau sangat setuju terhadap pernyataan remaja perempuan menikah pada umur <20 tahun, maka responden tidak mendukung program pemerintah yakni program Generasi Berencana yang salah satunya adalah upaya dalam Pendewasaan Usia Perkawinan (BKKBN, 2017b).

Kesuksesan sebuah keluarga tentunya tidak terlepas dari peran penting orang tua. Hasil penelitian yang dilakukan oleh Wahyuningsih \& Nurul (2016) menyebutkan bahwa tingkat kejadian pernikahan dini pada perempuan di bawah usia 21 tahun memiliki hubungan erat dengan peran orang tua. Saat peran orang tua baik maka tingkat kejadian pernikahan dini akan menurun, sebaliknya jika peran orang tua kurang maka tingkat kejadian pernikahan dini akan meningkat, sehingga agar tingkat kejadian pernikahan dini menurun maka-orang tua harus memiliki peran yang baik kepada anaknya (Wahyuningsih \& Nurul, 2016).

Penelitian antara hubungan pernikahan dini dengan peran orang tua juga telah dilakukan oleh Purwaningsih \& Ria (2014) yang menyatakan bahwa terdapat relasi antara pola asuh orang tua dengan pernikahan dini. Pola asuh tersebut salah satunya adalah diwujudkan dalam bentuk peran orang tua terutama dalam hal mengambil keputusan pada waktu anaknya akan menikah. Peran orang tua menjadi sangat penting, sehingga pernikahan yang terjadi pada anak yang masih berusia dini sangat dipengaruhi oleh orang tua, karena orang tua mempunyai peranan yang sangat besar di dalamnya.

\section{Kesehatan Reproduksi Remaja (KRR)}

Pemahaman mengenai kesehatan reproduksi remaja menjadi hal yang krusial baik bagi diri remaja sendiri maupun bagi keluarga yang mempunyai anggota keluarga berusia remaja. Pemahaman mengenai KRR ini didapatkan dari pemberian informasi yang bertujuan untuk meningkatkan pengetahuan remaja dan keluarganya khususnya mengenai KRR yang berguna dalam menyiapkan Generasi Berencana.

Berdasarkan hasil survey RPJMN 2017 didapatkan data bahwa masih ada keluarga yang dalam hal ini adalah orang tua remaja baik di Indonesia maupun di Jawa Timur yang sama sekali tidak pernah mendengar, melihat dan atau membaca informasi berkaitan dengan KRR.

Penelitian yang dilakukan oleh Oktavia et.al., (2018) yang menyatakan bahwa orang tua memiliki peranan yang berpengaruh dalam peningkatan pengetahuan remaja mengenai KRR. Terbatasnya pengetahuan remaja tentang kesehatan reproduksi remaja salah satunya di pengaruhi oleh lingkungan yang tidak menganggap penting pengetahuan mengenai risiko pernikahan dini serta anggapan dari masyarakat yang tabu jika membahas atau mencari tahu mengenai kesehatan reproduksi. Faktor lingkungan yang dimaksukan adalah orang tua dan keluarga yang mempunyai anggota remaja. Rendahnya pengetahuan remaja mengenai KRR berdampak pada 
perilaku seksual remaja menuju ke arah yang sangat membahayakan.

Penelitian lain juga menyatakan bahwa bahwa terdapat perbedaan pengetahuan tentang kesehatan reproduksi pada remaja setelah dilakukan paparan informasi mengenai KRR di mana sebelum dilakukan paparan dan dilakukan uji coba awal didapatkan hasil bahwa remaja yang memiliki pengetahuan kurang sebanyak $88,5 \%$ dan yang memiliki pengetahuan baik sebanyak $11,5 \%$. Setelah dilakukan paparan informasi mengenai KRR melalui metode penyuluhan dengan menggunakan media berupa slide power point dan leaflet sebagai pendukung media penyuluhan yang kemudian dilanjutkan dengan pelaksaan post-test maka didapatkan hasil bahwa remaja yang memiliki pengetahuan kurang sebanyak $46,2 \%$ dan yang memiliki pengetahuan baik sebanyak $53,8 \%$. Hal ini menunjukkan bahwa terdapat hasil yang sangat berbeda mengenai tingkat pengetahuan pada remaja sebelum dan sesudah terpapar oleh informasi mengenai KRR (Madinah, et.al., 2017).

Informasi mengenai KRR ini bisa didapatkan dari berbagai macam sumber baik yang bersumber dari media massa, media elektronik maupun media cetak.

Hasil dari SDKI KRR 2017 menyebutkan bahwa televisi masih merupakan media informasi yang paling populer; $81 \%$ remaja wanita dan $77 \%$ remaja pria menonton televisi paling sedikit sekali dalam seminggu. Keterpajanan terhadap media informasi lainnya seperti media cetak dan radio mulai terbatas.

Hal ini sesuai dengan data dari hasil survey indikator RPJMN tahun 2017 yang menggambarkan bahwa di Indonesia dan Jawa Timur keluarga yang mempunyai anggota keluarga berusia remaja mengetahui informasi mengenai KRR dari media televisi yakni di Indonesia sebesar $88,20 \%$ dan di Jawa Timur sebesar 90,20\%.

Televisi merupakan salah satu media elektronik yang sampai dengan saat ini masih paling banyak digunakan oleh masyarakat. Televisi memiliki pengaruh yang sangat besar jika dibandingkan media massa lainnya. Hal ini sesuai dengan penelitian yang dilakukan oleh Lago (2017) menyebutkan bahwa televisi merupakan media informasi yang menjadi media massa yang mengingatkan khalayak sasaran terhadap pesan yang disampaikan. Penggunaan televisi dalam penyampaian informasi melalui media audio visual mampu menimbulkan kesan yang lebih baik. Televisi mempunyai kemampuan dalam membangun image, pesan yang disampaikan melalui televisi mempunyai cakupan, jangkauan dan repetisi yang tinggi dan dapat menampilkan pesan multimedia (suara, gambar, dan animasi) yang dapat lebih mudah menarik perhatian para pemirsanya.

Penelitian lain juga menyebutkan bahwa televisi merupakan media pengantar pesan informasi ke masyarakat luas dalam penyampaian informasi yang terkait kebijakan, respon ataupun nasehat kepada masyarakat (Mukaromah \& Onny, 2016). Melalui media televisi yang menampilkan audio visual, masyarakat menjadi mudah memahami dan memaknai pesan yang di sampaikan melalui televisi. Penelitian yang dilakukan oleh Soedarsono (2012) juga menyebutkan bahwa kegiatan yang berorientasi pendidikan terutama dalam hal penyebaran informasi tidak cukup dilakukan di dalam koloni keluarga, kelompok sosial maupun masyarakat saja, peran yang begitu besar dari media massa terutama televisi dalam memberikan pengaruh terhadap khalayak penonton (Soedarsono, 2012).

Berdasarkan beberapa uraian di atas dapat disimpulkan bahwa dalam rangka mengoptimalkan program GenRe yang berkaitan dengan penyampaian informasi mengenai Kesehatan Reproduksi Remaja (KRR) media massa televisi masih merupakan pilihan utama yang dapat digunakan. Penyampaian pesan-pesan yang komunikatif, edukatif dan persuasif serta yang bersifat penting maupun yang berupa iklan dapat disampaikan melalui media televisi dengan tidak mengesampingkan penyampaian pesan melalui media komunikasi yang lain demi suksesnya program GenRe.

Sumber informasi mengenai KRR dapat disampaikan oleh tenaga kesehatan, guru, dan tokoh masyarakat serta tokoh agama di sekitar para remaja dan orang tua/keluarga yang mempunyai anggota keluarga yang berusia remaja

Data dari hasil survei indikator RPJMN tahun 2017 juga menggambarkan bahwa di Indonesia dan di Jawa Timur keluarga yang mengetahui informasi tentang KRR sebagian besar berasal dari Bidan atau perawat yakni di Indonesia sebesar 45,60\% dan di Jawa Timur sebesar 42,20\%. Selain Bidan/perawat Dari table tersebut juga menggambarkan bahwa 
petugas Petugas Lapangan Keluarga Berencana (PLKB) dan Penyuluh KB juga mempunyai peran yang besar dalam menyampaikan informasi mengenai KRR.

Penelitian yang dilakukan oleh Erlina Hayati, et.al., (2016) menyebutkan bahwa petugas kesehatan khususnya bidan memiliki peran yang sangat penting dalam menyampaikan informasi kepada masyarakat termasuk informasi mengenai KRR. Penyampaian informasi ini dapat dilakukan melalui komunikasi persuasif. Komunikasi persuasif merupakan suatu proses komunikasi dimana terdapat usaha untuk meyakinkan orang lain agar publiknya berbuat dan bertingkah laku seperti yang diharapkan orang yang menyampaikan pesan. Komunikasi persuasif yang dilakukan tenaga kesehatan pada saat konseling dan penyampaian informasi dapat mempengaruhi pengetahuan dan sikap responden untuk memahami dan mematuhi pesan yang disampaikan.

Bidan/perawat dan Petugas Lapangan Keluarga Berencana (PLKB)/Penyuluh KB mempunyai peran yang sangat penting dalam mendukung suksesnya program GenRe khususnya yang terkait dengan KRR. Oleh karena itu petugas kesehatan harus senantiasa meningkatkan kinerja dan menjaga mutu kinerjanya khususnya dalam hal penyampaian informasi mengenai Kesehatan Reproduksi pada remaja dan keluarganya dan tetap mengembangkan kerjasama pada stake holder terkait, lintas program dan lintas sektor dengan melibatkan semua unsur yang terdapat dalam masyarakat guna mengoptimalkan program GenRe.

Indeks pengetahuan mengenai KRR baik pada remajanya sendiri maupun pada keluarga yang memiliki remaja yang berasal dari media maupun dari petugas yang menyampaikan informasi di Indonesia dan di Jawa Timur masih sangat rendah yakni baru mencapai 37,6\% dan pada tahun 2017 mulai terjadi peningkatan trend setelah turun drastis pada tahun 2016. Melihat gambaran trend indeks pengetahuan mengenai KRR baik pada remajanya sendiri maupun pada keluarga yang memiliki remaja tersebut maka perlu dilakukan upaya yang serius dalam meningkatkan penyebarluasan informasi mengenai. Sesuai dengan Renstra BKKBN 2015-2019 menyebutkan bahwa indeks pengetahuan remaja tentang KRR pada tahun 2018 harus mencapai $51 \%$ dari total remaja yang ada.
Upaya penyebarluasan informasi mengenai KRR baik melalui media massa, media elektronik, media cetak maupun melalui petugas kesehatan dan tokoh masyarakat harus senantiasa di tingkatkan baik dari segi kuantitatif dan kualitatif demi suksesnya program GenRe di masa yang akan datang.

\section{Bina Keluarga Remaja (BKR) dan Pusat Informasi dan Konseling Remaja/ Mahasiswa (PIK Remaja / Mahasiswa)}

PIK Remaja/Mahasiswa merupakan salah satu bentuk kegiatan yang dikembangkan oleh program GenRe yang sistem pengelolaannya dari, oleh dan untuk Remaja/Mahasiswa. Kegiatan dalam PIK Remaja/Mahasiswa diantaranya adalah pemberian informasi dan konseling tentang PUP, delapan fungsi keluarga, dan tiga ancaman bagi remaja yang dikenal dengan istilah TRIAD KRR yang meliputi seksualitas, HIV dan AIDS serta NAPZA, ketrampilan hidup, gender dan ketrampilan advokasi dan KIE (Komunikasi, Informasi dan Edukasi) (BKKBN, 2014).

BKR merupakan suatu bentuk kegiatan yang dikembangkan program GenRe yang mempunyai anggota para keluarga yang mempunyai remaja berusia 10-24 tahun. Tujuan dari kegiatan BKR adalah untuk meningkatkan pengetahuan dan keterampilan orangtua dan anggota keluarga lainnya dalam pengasuhan, pembinaan dan pengawasan tumbuh kembang remaja, meningkatkan kesertaan para orang tua/keluarga lainnya dalam kegiatan pembinaan dan kemandirian ber KB (BKKBN, 2012).

Berdasarkan hasil dari trend rekapitulasi keluarga jadi sasaran pembinaan ketahanan keluarga kelompok BKR Provinsi Jawa Timur periode Desember 2017 sampai dengan bulan Juni Tahun 2018 didapatkan data bahwa keluarga yang menjadi sasaran kelompok BKR Provinsi Jawa Timur pada bulan Desember 2017 sebesar $25,67 \%$. Tetapi sampai dengan bulan Juni tahun 2018 persentase keluarga jadi sasaran kelompok BKR Provinsi Jawa Timur turun menjadi 24,72 \%. Penurunan trend tersebut menunjukkan bahwa paya untuk meningkatkan pengetahuan dan keterampilan orangtua serta anggota keluarga lainnya dalam pengasuhan, pembinaan dan pengawasan tumbuh kembang para remaja, upaya untuk meningkatkan kesertaan para orang tua/keluarga lainnya dalam kegiatan 
pembinaan dan kemandirian ber $\mathrm{KB}$ juga mengalami penurunan. Hal tersebut juga menunjukkan bahwa program BKR belum berjalan secara Optimal. Mengingat bahwa BKR merupakan salah satu kegiatan yang menjadi suksesnya program Generasi Berencana maka masalah tersebut perlu kita waspadai dan perlu mendapatkan penyelesaian.

\section{SIMPULAN DAN SARAN}

\section{Simpulan}

Program GenRe yang dilaksanakan di Indonesia dan di Jawa Timur berdasarkan hasil Survei Indikator RPJMN 2017 masih belum berjalan dengan baik Hal ini ditunjukkan dengan belum berhasilnya pelaksanaan Program Pendewasaan Usia Perkawinan (PUP) di mana angka pernikahan pada remaja masih tinggi dan masih rendahnya keterpaparan informasi pada remaja dan keluarganya mengenai KRR, BKR dan PIK R/M.

\section{Saran}

Dalam rangka mengoptimalkan pelaksanaan program GenRe hal yang di sarankan dari hasil analisis penelitian ini di antaranya adalah dengan meningkatkan pengetahuan dan kesadaran melalui keterpaparan informasi yang berkaitan dengan PUP, KRR, BKR dan PIK Remaja/ Mahasiswa baik melalui media massa maupun melalui informasi yang disampaikan oleh petugas kesehatan dan tokoh masyarakat pada remaja dan keluarga yang mempunyai anggota keluarga berusia remaja serta pada masyarakat luas, meningkatkan dan menjalin erat kerja sama lintas program di lingkup internal dan lintas sektor di wilayah eksternal yang meliputi semua jejaring dan jaringan kerja di wilayah kerja BKKBN provinsi Jawa Timur dalam upaya optimalisasi pelaksanaan Program GenRe yang terdiri dari tiga hal penting di antaranya PUP, KRR, BKR dan PIK Remaja/mahasiswa.

\section{DAFTAR PUSTAKA}

BPS. 2013. Proyeksi Penduduk Indonesia Indonesia Population Projection 20102035. Jakarta: Badan Pusat Statistik.

Banderan, D.W.K., Dali, R., Lapolo, N. 2017. Faktor-faktor yang Mempengaruhi Perkawinan Usia Muda di Provinsi
Gorontalo. Jurnal Keluarga Berencana, [ejournal] 2 (1): pp. 34-42.

BKKBN. 2012. Pengelolaan Bina Keluarga Remaja (BKR). Jakarta: Badan Kependudukan dan Berencana Nasional Direktorat Bina Ketahanan Remaja.

BKKBN. 2014. Pedoman Pengelolaan Pusat Informasi dan Konseling (PIK R/M). Jakarta: Drektorat Bina Ketahanan Remaja.

BKKBN Provinsi Jawa Timur. 2014. GenRe Generasi Berencana. Surabaya: Perwakilan Badan Kependudukan dan Keluarga Berencana Nasional Provinsi Jawa Timur.

BKKBN. 2017a. Survei Indikator Kinerja Program KKBPK RPJMN Keluarga. Jakarta: Badan Kependudukan dan Berencana Nasional.

BKKBN. 2017b. Survei Kependudukan, Keluarga Berencana, Kesehatan Reproduksi Remaja dan Pembangunan Keluarga di Kalangan Remaja Indonesia. Jakarta: Badan Kependudukan dan Berencana Nasional.

Desiyanti, I.W. 2015. Faktor-Faktor yang Berhubungan Terhadap Pernikahan Dini Pada Pasangan Usia Subur di Kecamatan Mapanget Kota Manado. Jikmu, [e-journal] 5 (2), pp. 270-280.

Hayati, E., Amir, P., Asfriyati. 2016. Pengaruh Komunikasi Persuasif Bidan Terhadap Pengetahuan dan Sikap Ibu Tentang Pemberian MP-ASI Di Desa Pasar Maga Kecamatan Lembah Sorik Merapi Kabupaten Mandailing Natal Tahun 2016. Jurnal Penelitian Pendidikan Sosial Humaniora, [e-journal] 1 (2): pp. 72-79.

Lago, M.N. 2017. Eksploitasi Tubuh Perempuan Di Media Televisi (Analisis Semiotika Makna Pesan Iklan Cat Avian Syntetic Versi Awas Cat Basah). Jurnal Online Kinesik, [e-journal] 30 (2): pp. 3036.

Madinah, S., Rahfiludin, Z., Nugrahaeni, S.A. 2017. Pengaruh Pendidikan Kesehatan Reproduksi Terhadap Tingkat Pengetahuan Tentang Pendewasaan Usia Perkawinan. Jurnal Kesehatan Masyarakat, [e-journal] 5 (1): pp. 332-340.

Mahfudin, A., Khoirotul, W. 2016. Pernikahan Dini dan Pengaruhnya terhadap Keluarga di Kabupaten Sumenep Jawa Timur. Jurnal Hukum Keluarga Islam, [e-journal] 1 (1): pp. 33-49.

Peraturan Menteri Kesehatan Republik Indonesia Nomor 25 Tahun 2014 Tentang 
Upaya Kesehatan Anak. Jakarta: Kementerian Kesehatan Republik Indonesia.

Mukaromah, A., Onny, F.S. 2016. Komunikasi Eksternal Divisi Hubungan Masyarakat Kepolisian Republik Indonesia. Jurnal Utilitas, [e-journal] 2 (1): pp. 30-38.

Oktavia, E.R., Agustin, F.R., Magai, N.M., Cahyati, W.H. 2018. Pengetahuan Risiko Pernikahan Dini pada Remaja Umur 13-19 Tahun. Higeia Journal of Public Health, [ejournal] 2 (186): pp. 239-248.

Purwaningsih, E., Ria, T.S. 2014. Hubungan Pola Asuh Orang Tua Dengan Kejadian Pernikahan Usia Dini di Desa Jambu Kidul, Ceper, Klaten. Journal Involusi Kebidanan, [e-journal] 4 (7), pp. 1-12.
Soedarsono, D.K. 2012. Pesan Komunikasi Pendidikan Di Media Televisi. Jurnal Ilmiah Komunikasi |MAKNA, [e-journal] 2 (2): pp. 49-57.

Undang-Undang Republik Indonesia Nomor 52 Tahun 2009 Tentang Perkembangan Kependudukan dan Pembangunan Keluarga. Jakarta: Kementerian Koordinator Bidang Pembangunan Manusia dan Kebudayaan Republik Indonesia.

Wahyuningsih, S.A., Nurul, S. 2016. Hubungan Tingkat Kejadian Pernikahan Dini Dengan Peran Orang Tua Pada Perempuan Di Bawah 21 Tahun Di desa Sidoarum Kecamatan Godean Kabupaten Sleman Yogyakarta. Naskah Publikasi. Universitas 'Aisyiyah Yogyakarta. 